\title{
Experimental Investigation and Theoretical Analysis on the Performance of Tube-Sheet Photovoltaic Thermal (PV/T) Collectors
}

\author{
Gaojie Yang ${ }^{1}$, Wei Zhao ${ }^{2}$, Guoqing $\mathrm{Yu}^{1,{ }^{1}}$ and Hongzhi Liü ${ }^{2}$ \\ ${ }^{1}$ University of Shanghai for Science and Technology, Shanghai, 200093, China \\ ${ }^{2}$ Fadian (Sanmenxia) Urban Heating Co., Ltd. Sanmenxia, 472000, Henan, China
}

\begin{abstract}
The PV/T collectors realize the simultaneous output of electricity and thermal energy, which are more efficient than the separated photovoltaic (PV) or solar thermal collectors. In this paper, the electricity generation and thermal collection performances of tube-sheet PV/T collector are studied. The main research contents are as follows: an experimental test system of PV/T collector was built to test the electricity generation and thermal collection performances of tube-sheet PV/T at an inlet water temperature of $30^{\circ} \mathrm{C}$. Moreover, the flow resistance test was carried out. In addition, the theoretical heat transfer model was established, and the thermal performance was calculated by theoretical analysis. The experimental data showed that the daily average temperature difference between the PV panel and the inlet water temperature was about $22.5^{\circ} \mathrm{C}$. The daily average electrical efficiency was about $9.25 \%$, and the daily average thermal efficiency was about $28.67 \%$. The theoretical analysis of the tube-sheet PV/T model was carried out, and the calculated results were close to the experimental results. The main reason for the large temperature difference between the PV panel and water temperature was that the combined thermal resistance between the PV panel and the absorber plate was large, and reducing the combined thermal resistance could reduce the temperature of the PV panel. The effects of solar irradiance, ambient temperature and spacing of row tubes on the performance of thermal collection were analyzed to optimize the $\mathrm{PV} / \mathrm{T}$ performance.
\end{abstract}

Keywords: PV/T collector, Tube-sheet, Thermal collection performance, Experimental test, Theoretical calculation.

\section{INTRODUCTION}

At present, solar energy utilization technology is one of the fastest-growing technologies in the development and utilization of renewable energy. Solar energy has become one of the most important renewable energy sources in the world.

Solar photovoltaic thermal (PV/T) utilization refers to the use of solar photovoltaic (PV) cells to generate electricity and the utilization of heat by adding a fluid channel on the back of the PV panel at the same time. $\mathrm{PV} / \mathrm{T}$ technology not only takes into account the negative temperature characteristics of PV cells but also realizes the simultaneous output of thermal energy and electricity. Compared with the single solar PV or thermal technology, the PV/T technology is more effective to increase the utilization rate of solar energy.

The concept of the PV/T system was first proposed in the 1970s [1]. Florschuetz [2] established the Extention Hottel-Whillieras the PV/T module based on the theoretical model of the flat plate thermal collector. Bergene and Lovvik [3] established an algorithm to calculate the thermal efficiency and electrical efficiency of the PV/T system. With the widespread utilization of

${ }^{*}$ Address correspondence to this author at the University of Shanghai for Science and Technology, Shanghai, 200093, China; Tel: +8613512168956; E-mail: yuguoqinghvac@163.com solar energy, the research on $\mathrm{PV} / \mathrm{T}$ collector is also constantly innovating and developing.

Chow et al. [4] studied the performance of flat aluminium box $\mathrm{PV} / \mathrm{T}$ modules through experiments, analyzed influencing factors and proposed directions for optimization. Ibrahim et al. [5] reviewed the research states of flat $\mathrm{PV} / \mathrm{T}$ modules with a variety of structures and different cooling mediums. They concluded that the simple structure of tube-sheet and liquid-cooled $\mathrm{PV} / \mathrm{T}$ modules have advantages of integrated thermoelectric efficiency and economy. Dupeyrat et al. [6] proposed that the performance of $\mathrm{PV} / \mathrm{T}$ module could be optimized by improving the heat transfer performance between the PV module and the heat exchange fluid water. Fudholi et al. [7] designed three new water-cooled PV/T devices of web flow type, direct flow type and spiral flow type, and conducted experiments to study their electrical and thermal performances. The results showed that the efficiency of PV module increased when the temperature was lowered. The decrease of temperature was not linear with the increase of mass flow rate. However, when the mass flow rate reached $0.024 \mathrm{~kg} / \mathrm{s}$, the temperature would decrease significantly. In general, the efficiency of $\mathrm{PV} / \mathrm{T}$ modules increases with the mass flow rate at various solar radiation levels. Asteet et al. [8] developed a flat PV/T with analuminiumroll-bond as an absorber and established a simulation model to 
evaluate the thermal and electrical performance of this structure.

Ramdani and Ould-Lahoucine [9] used ANSYS Fluent software to simulate a new type of PV/T module with a water channel placed on top of the PV panel. The simulation involved the effects of internal parameters (the height of the cooling channel and the inlet water velocity) and external parameters (wind speed, solar radiation and ambient temperature) on the overall energy and exergy performances of PV/T. The results showed that in terms of energy quantity and quality, the $P V / T$ is better than the $P V / T$ proposed previously. Bilbao and Sproul [10] proposed a new nodal approach based on electrical-thermal analogy using thermal networks to simulate the instantaneous thermal response of water-cooled PV/T module. The approach was validated the experimental result. Sakellariou and Axaopoulos [11] established a firstorder dynamic model for PV/T collector to estimate the average temperature of the absorber through an iterative process by using the analytic solution of the energy balance equation of the collector. The validity of the model was proved by the experimental data. Turkyilmazoglu [12-14] studied the heat transfer process and efficiency of the fin through the solution and analysis of physical parameters. The results find that shrinking fins lead to higher efficiency than the stretching fins, and exponential porous wet fins proved to have higher efficiency than the straight porous fins. The growing shaped fin has great thermal performance and fin efficiency which show a good market prospect.

Zhou et al. [15] built a three-dimensional thermal performance model of a serpentine tube water-cooled flat PV/T collector by using the finite element method and verified the simulation accuracy through experimental data. At the same time, the influences of various factors of tube spacing, absorber material, inlet velocity and tube arrangement on the temperature distribution were studied. The results showed that reducing tube spacing was the most effective way to increase the uniformity of temperature distribution, and the use of absorber material with better thermal properties could partially improve the temperature distribution. Yu et al. [16] used experimental and TRNSYS simulation methods to study the performances of an unglazed roll-bond water-type PV/T under the climatic conditions of the Sichuan Basin of China.

In this paper, a tube-sheet PV/T collector is manually assembled by using a tube-sheet collector. The performances of electricity generation and thermal collection of PV/T are tested experimentally, and a heat transfer model is further established for theoretical analysis and calculation. The main influencing parameters and optimization of the tube-sheet PV/T collector are analyzed.

\section{EXPERIMENTAL SETUP OF TUBE-SHEET PV/T COLLECTOR}

In this study, the experimental setup of a tube-sheet $\mathrm{PV} / \mathrm{T}$ collector was built to test the electrical performance, thermal performance and flow resistance of the tube-sheet PV/T collector.

\subsection{Configuration and Dimensions of the PV/T Collector}

The diagram of a cross-sectional structure of the tube-sheet $P V / T$ collector is shown in Figure 1 . It mainly consists of glass cover, air space, PV panel, absorber plate, tubes and insulation layer from the top to bottom. The ratio of the area of the PV cells to the

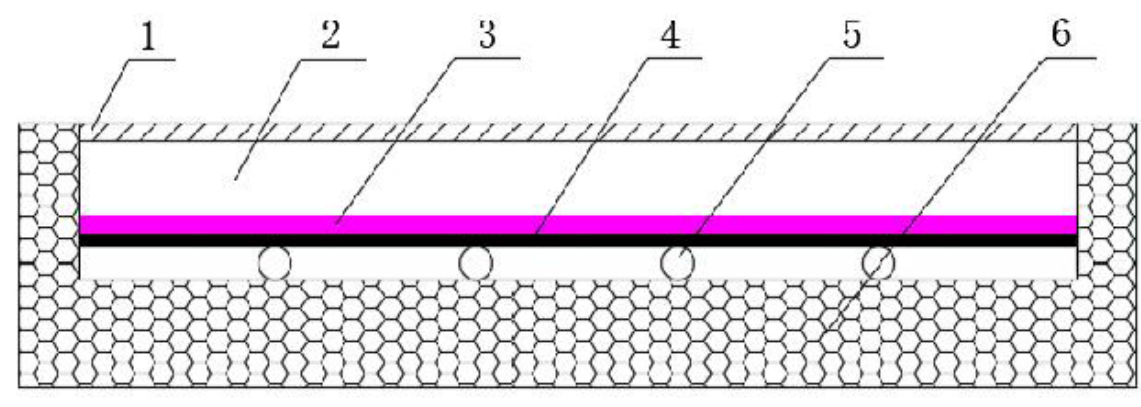
1. Glass cover
2. Air space
3. PV panel
4. Absorber plate
5. Tubes
6. Insulation layer

Figure 1: Sectional structure diagram of tube-sheet PV/T. 
absorber plate in the $\mathrm{PV} / \mathrm{T}$, that is, the cell coverage is about $64 \%$.

The specific composition of the $P V$ panel is successively TPE insulating film, EVA insulating film, $P V$ cells, EVA insulating film and TPE insulating film. As shown in Figure 2, there are 4 copper tubes with an inner diameter of $8 \mathrm{~mm}$ in parallel, and two copper collecting tubes with an inner diameter of15 $\mathrm{mm}$. The absorber plate material is aluminium. The tube-sheet $\mathrm{PV} / \mathrm{T}$ is assembled on the basis of acommon tubesheet collector by sticking the back of the PV panel to the absorber plate through thermal conductivity adhesive, and then pasting the glass cover to the frame of the device with glass adhesive. It is assembled into $\mathrm{PV} / \mathrm{T}$ module. The main parameters of the tube-sheet $\mathrm{PV} / \mathrm{T}$ collector are shown in Table 1.

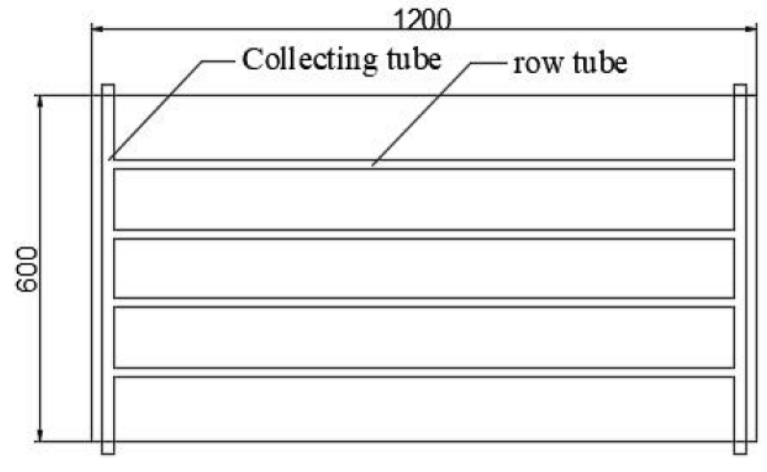

Figure 2: Plane of the tube-sheet PV/T structure.

\subsection{Schematic of the Experimental System}

The experimental test system of the tube-sheet $\mathrm{PV} / \mathrm{T}$ collector was built on the roof of the School of

Table 1: Main Parameters of the Tube-Sheet PV/T Collector

\begin{tabular}{|c|c|c|}
\hline Projects & Parameters & \\
\hline & Module size $(\mathrm{mm})$ & $1200 \times 60$ (Length $\times$ Width $)$ \\
\hline & Thickness of transparent glass cover $(\mathrm{mm})$ & 3.2 \\
\hline & Transmittance of glass cover $(\%)$ & 91.88 \\
\hline & Reflectance of glass cover (\%) & 7.63 \\
\hline & Absorptance of glass cover (\%) & 0.94 \\
\hline & Distance between glass cover and PV (mm) & 20 \\
\hline \multirow[t]{6}{*}{ PV module } & Peak Power $\left(P_{\max }\right)(W)$ & 80 \\
\hline & Peak Voltage $\left(\mathrm{V}_{\mathrm{mp}}\right)(\mathrm{V})$ & 18 \\
\hline & Peak Current $\left(I_{m p}\right)(A)$ & 4.44 \\
\hline & Open Circuit Voltage $\left(\mathrm{V}_{\mathrm{oc}}\right)(\mathrm{V})$ & 21.60 \\
\hline & Short Circuit Current $\left(I_{s c}\right)(A)$ & 4.88 \\
\hline & Cells & $\begin{array}{l}\text { Monocrystalline silicon solar cells (36 pieces) } \\
\qquad 156 \mathrm{~mm} \times 78 \mathrm{~mm}\end{array}$ \\
\hline \multirow[t]{6}{*}{ Thermal module } & Area of absorber plate $\left(\mathrm{m}^{2}\right)$ & 0.69 \\
\hline & Thickness of absorber plate $(\mathrm{mm})$ & 0.5 \\
\hline & $\begin{array}{l}\text { Thermal conductivity coefficient of absorber } \\
\text { plate }[\mathrm{W} /(\mathrm{m} \cdot \mathrm{K})]\end{array}$ & 202 \\
\hline & Row tubes diameter (Inner diameter) (mm) & 8 \\
\hline & Row tubes spacing (mm) & 120 \\
\hline & Thermal conductivity of fluid channel $[\mathrm{W} /(\mathrm{m} \cdot \mathrm{K})]$ & 385 \\
\hline \multirow[t]{4}{*}{ Insulation layer and frame } & Thickness of side insulation layer $(\mathrm{mm})$ & 25 \\
\hline & $\begin{array}{l}\text { Thermal conductivity of insulation layer } \\
{[\mathrm{W} /(\mathrm{m} \cdot \mathrm{K})]}\end{array}$ & 0.045 \\
\hline & Thickness of back insulation layer (mm) & 60 \\
\hline & Thickness of the frame $(\mathrm{mm})$ & 0.8 \\
\hline
\end{tabular}




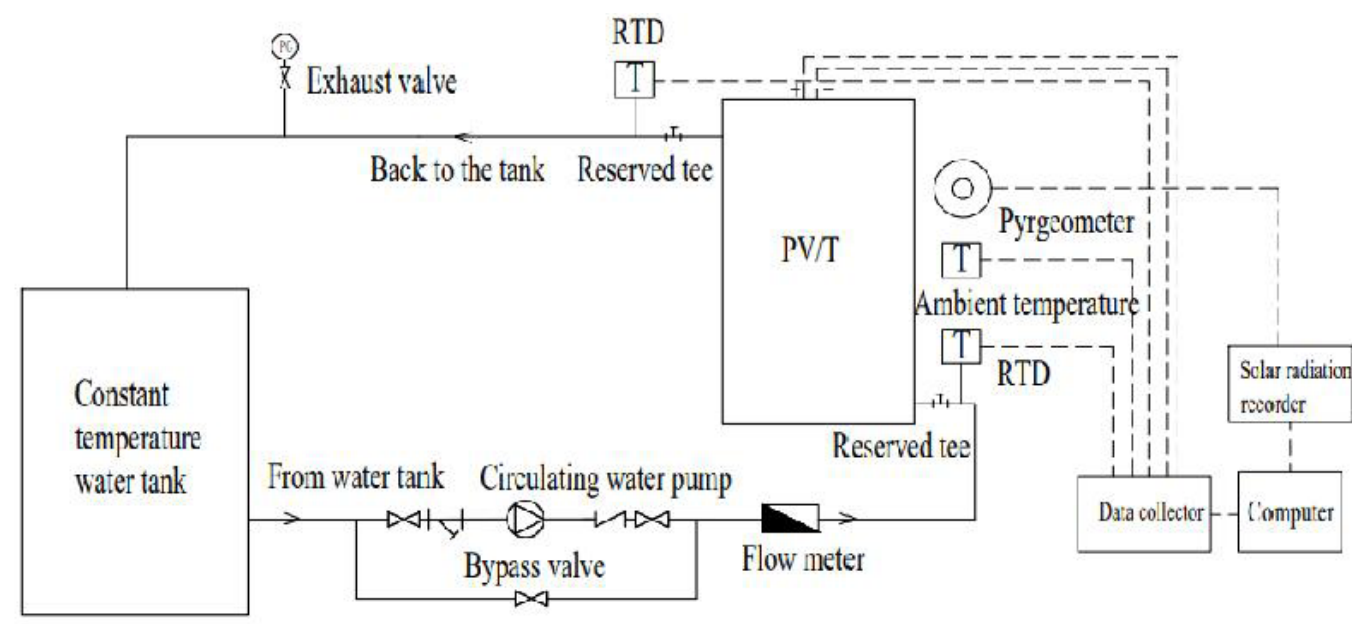

Figure 3: Schematic diagram of the experimental test system.

Environment and Architecture of the University of Shanghai for Science and Technology. The experimental test system mainly includes tube-sheet $\mathrm{PV} / \mathrm{T}$, constant temperature water tank, circulating water pump and water flow meter. The connection principle of the system is shown in Figure 3. The PV/T was placed on a bracket with an inclination of $30^{\circ}$ and facing south. During the test, thepyranometer connected to the solar radiation recorder and the PV/T collector is placed on the bracket together, then the irradiance measured by the pyranometer can be regarded as the solar irradiance per unit area received by the PV/T on the inclined surface. Nine T-type thermocouples are arranged on the surface of the PV panel. The schematic diagram of the arrangement points is shown in Figure 4.

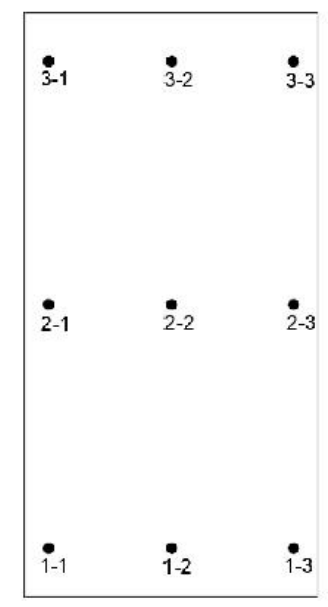

Figure 4: Schematic diagram of surface temperature test points of PV panel.

The picture of the experimental test system of PV/T collector is shown in Figure 5. The insulation material is used to wrap the circulation pipe of the whole system, which can reduce the influence of heat loss on the measured data. The inlet flow rate is $108 \mathrm{~L} / \mathrm{h}$ and the inlet water temperature is $30^{\circ} \mathrm{C}$.In order to ensure the performance of PVT collector at an ideal level, the inlet water temperature of $30^{\circ} \mathrm{C}$ is the most suitable temperature. The flow rates are manually adjusted by adjusting the bypass valves. The test method is proposed by $\mathrm{Yu}$ et al. [17]. The experimental test was carried out according to the experimental conditions, and the test was conducted under clear weather in December 2020.

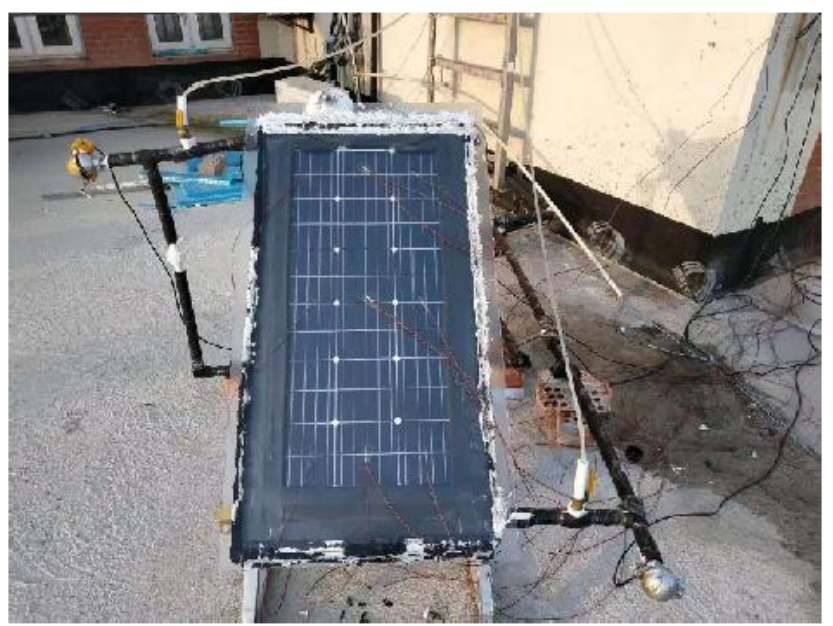

Figure 5: Physical photo of the experimental platform.

\subsection{Experimental test Parameters and Instruments}

There are some parameters to be tested, such as solar irradiance, outdoor ambient temperature, inlet water temperature, outlet water temperature, maximum output electric power of the $\mathrm{PV} / \mathrm{T}$, the surface 
Table 2: Experimental test Instruments

\begin{tabular}{|l|c|l|}
\hline \multicolumn{1}{|c|}{ Instruments } & Specifications & Applications \\
\hline \hline Solar radiation recorder & PC-2A & Collection of solar radiation on inclined plane \\
\hline Pyranometer & TBQ-2 & Measurement of solar irradiance on inclined plane \\
\hline Resistance Temperature Detector & 34972A & Measurement of inlet and outlet water temperature \\
\hline Agilent Data collector & Volumetrictype & Collection of inlet and outlet water temperature and \\
\hline Flow meter & PROVA-200A & Measurement of flow \\
\hline Solar module tester & T-type & $\begin{array}{l}\text { Measurement of ambient temperature and surface } \\
\text { temperature of PV panel }\end{array}$ \\
\hline Thermocouple & & \\
\hline
\end{tabular}

temperature of the PV panel, and the flow rate. The adopted instruments and their applications are shown in Table 2.

\subsection{Performance Evaluation Method of PV/T Collectors}

The comprehensive performance of PV/T collector is divided into photovoltaic and thermal, namely electrical and thermal performance.

The thermal energy collected by $\mathrm{PV} / \mathrm{T}$ is calculated in Eq.1 [18].

$Q_{w}=M_{w} c_{w}\left(T_{w, f}-T_{w, i}\right)$

Where $M_{w}$ is the mass flow rate of circulating water, $\mathrm{kg} / \mathrm{s} ; c_{w}$ is the specific heat capacity of water, $\mathrm{J} /(\mathrm{kg} \cdot \mathrm{K})$; $T_{w, i}$ and $T_{w, o}$ are the inlet water temperature and outlet water temperature of $\mathrm{PV} / \mathrm{T}$, respectively, $\mathrm{K}$.

The calculation equation of the thermal efficiency of $\mathrm{PV} / \mathrm{T}$ is shown in Eq. 2[18].

$\eta_{t}=\frac{Q_{w}}{G A_{c}} \times 100 \%$

Where $G$ is the solar irradiance per unit area received by $\mathrm{PV} / \mathrm{T}, \mathrm{W} / \mathrm{m}^{2}$; is the effective receiving area of sunlight by the absorber plate, $\mathrm{m}^{2}$.

The electrical efficiency of a PV/T device is defined as the ratio of the maximum electricity output to the amount of solar radiation incident on the surface of $\mathrm{PV} / \mathrm{T}$. The calculation equation is shown in Eq.3 [18].

$\eta_{P}=\frac{U}{G A_{P}} \times 100 \%$
Where $U$ is the working voltage of $\mathrm{PV} / \mathrm{T}, \mathrm{V} ; I$ is the working current of PV/T, $\mathrm{A} ; A_{p}$ is the area of the $\mathrm{PV}$ panel, $\mathrm{m}^{2}$.

\section{EXPERIMENTAL ANALYSIS OF THE TUBE- SHEET PV/T COLLECTOR}

In this section, the relevant data of electrical performance, thermal performance and flow resistance tested according to the experimental conditions are summarized and analyzed.

\subsection{Electrical and Thermal Performances of the Tube-Sheet PV/T Collector}

The inlet water temperature was adjusted to $30^{\circ} \mathrm{C}$ to test the thermal performance and electrical performance of the tube-sheet $\mathrm{PV} / \mathrm{T}$ collector, and the data of stable time was taken as the effective experimental data.

The test date was $20^{\text {th }}$ December. The daily solar irradiance and out door ambient temperature recorded under the inlet water temperature of $30^{\circ} \mathrm{C}$ are shown in Figure 6. It can be seen from Figure 6 that solar irradiance fluctuates greatly from 10:30 to 12:00. The ambient temperature also fluctuates greatly during the same period. After the beginning of the test, the outdoor temperature gradually increased for a period of time, and then the overall temperature was around $10^{\circ} \mathrm{C}$.

As shown in Figure 7, under the test conditions of the tube-sheet $\mathrm{PV} / \mathrm{T}$, the average surface temperature of the PV panel (the average of the nine temperature measuring points on the surface) is on the whole with the change of the solar irradiance. Due to the existence of glass cover and air layer, its temperature is not affected greatly by the outdoor ambient temperature, 


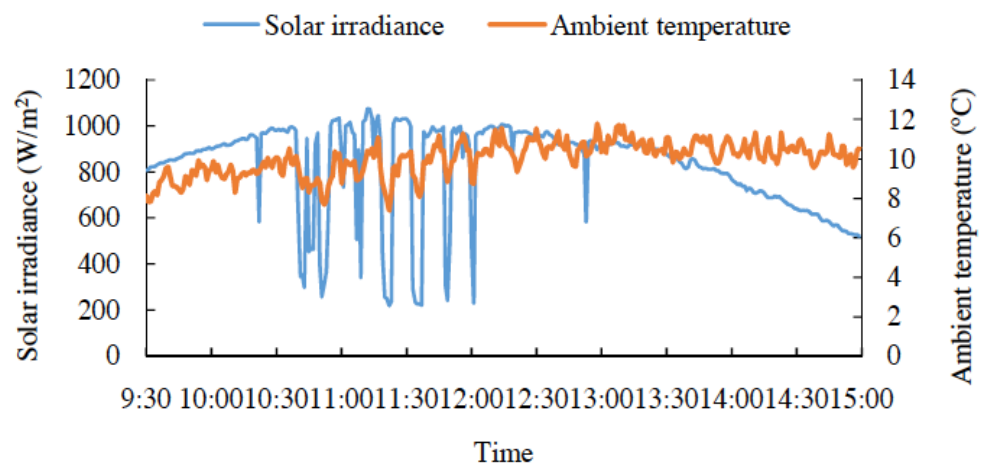

Figure 6: Solar irradiance and outdoor ambient temperature.

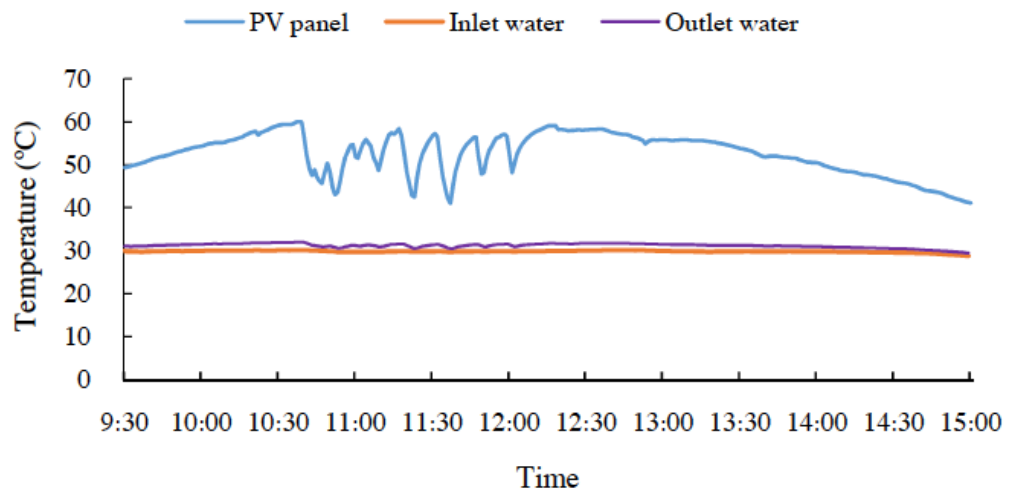

Figure 7: Inlet water temperature, outlet water temperature and average surface temperature of PV panel.

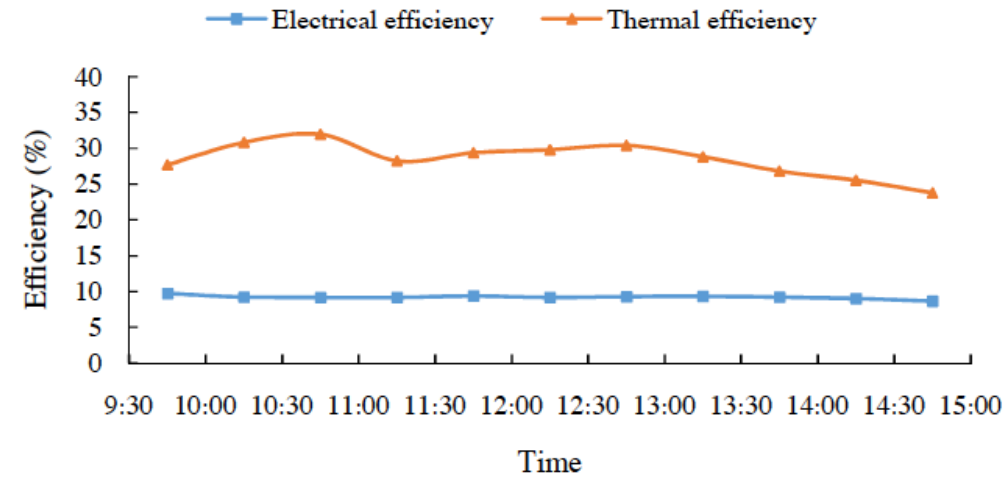

Figure 8. Electrical efficiency and thermal efficiency of tube-sheet PV/T.

and the rising rate is fast. And the decay rate is slow when the irradiance is weakened so that the thermal efficiency and electrical efficiency have a corresponding delay. When the performance is stable, the average daily temperature difference between the $\mathrm{PV}$ panel and the inlet water temperature is about $22.5^{\circ} \mathrm{C}$. The daily average electrical efficiency is $9.25 \%$, and the daily average thermal efficiency is $28.67 \%$. Both electrical efficiency and thermal efficiency increase with the rise of solar irradiance. However, the increase of the temperature of the PV panel will reduce the increment of the corresponding electrical efficiency. The PV cells temperature gradually increases, so the electrical efficiency decreases after the start of the test.

The summary of the experimental results of the tube-sheet PV/T collector within the test time under the inlet water temperature of $30^{\circ} \mathrm{C}$ is shown in Table 3 and Table 4. To sum up, under normal operation conditions, the electrical efficiency decreases as the temperature of the PV panel rises, and increases as the solar irradiance increase. However, under high solar irradiance, the electrical efficiency does not 
Table 3: Experiment Results of Tube-Sheet PV/T Collector

\begin{tabular}{|c|c|c|c|c|c|c|}
\hline $\begin{array}{l}\text { Working } \\
\text { condition }\end{array}$ & $\begin{array}{c}\text { Daily Average } \\
\text { Ambient } \\
\text { Temperature }\left({ }^{\circ} \mathrm{C}\right)\end{array}$ & $\begin{array}{l}\text { Daily Total Solar } \\
\text { Radiation } \\
\left(\mathrm{MJ} / \mathrm{m}^{2}\right)\end{array}$ & $\begin{array}{l}\text { Daily Average } \\
\text { Outlet Water } \\
\text { Temperature }\left({ }^{\circ} \mathrm{C}\right)\end{array}$ & $\begin{array}{l}\text { Daily Average } \\
\text { Temperature of } \\
\left.\text { PV Panel ( }{ }^{\circ} \mathrm{C}\right)\end{array}$ & $\begin{array}{c}\text { Daily Total } \\
\text { Electricity } \\
\text { Generation (MJ) }\end{array}$ & $\begin{array}{l}\text { Daily Total } \\
\text { Thermal } \\
\text { Collection (MJ) }\end{array}$ \\
\hline $\begin{array}{c}\text { Inlet water } \\
\text { temperature } 30^{\circ} \mathrm{C}\end{array}$ & 10.01 & 16.29 & 31.21 & 52.57 & 0.58 & 3.18 \\
\hline
\end{tabular}

Table 4: Daily Average Efficiency of Tube-Sheet PV/T Collector

\begin{tabular}{|c|c|c|}
\hline Working Condition & Electrical Efficiency (\%) & Thermal Efficiency (\%) \\
\hline \hline Inlet water temperature $30^{\circ} \mathrm{C}$ & 9.25 & 28.67 \\
\hline
\end{tabular}

change significantly. The temperature of $\mathrm{PV}$ panel increases with the solar irradiance so that the thermal efficiency increases with the temperature difference between the inlet water and the PV panel.

\subsection{Pressure Drop of the Tube-Sheet PV/T Collector}

By adjusting the opening of the bypass valve to change the system flow, the flow resistance of the tube-sheet $\mathrm{PV} / \mathrm{T}$ collector was tested at different flow rates. The test results are shown in Figure 9. As can be seen from Figure 9, the pressure loss of tube-sheet $\mathrm{PV} / \mathrm{T}$ generally changes in a quadratic relationship with the flow rate, and the pressure loss is not very large. The main reason is that the tube-sheet flow channel is a copper tube with a smooth surface, and the pressure loss is mainly along with the frictional, split and confluence loss.

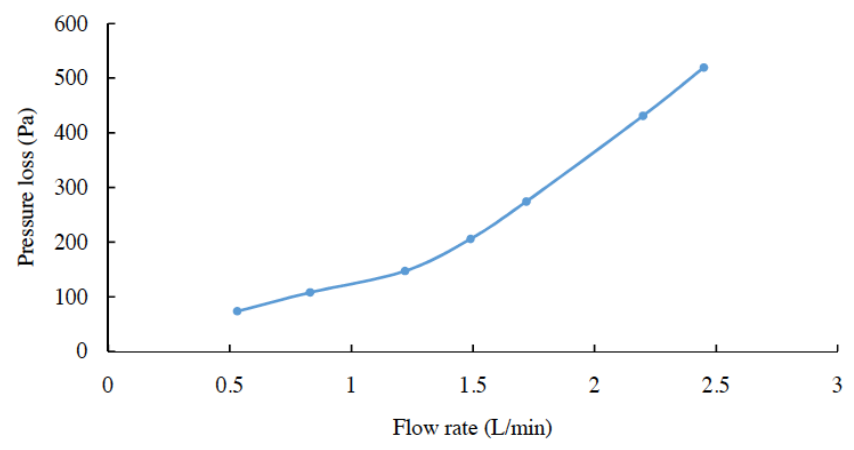

Figure 9: Flowing pressure loss of tube-sheet PV/T.

\section{THEORETICAL ANALYSIS OF THE TUBE-SHEET PV/T COLLECTOR}

In this section, based on the analysis of the experimental results in the previous section, a theoretical mathematical model of tube-sheet $P V / T$ collector is established. The heat transfer process is analyzed and solved by combining the design variables in the experiment.

\subsection{Simplification and Assumption of the Analysis}

Part of the solar radiation energy received by the $\mathrm{PV} / \mathrm{T}$ surface becomes useful energy, that is, converted into electrical energy and thermal energy, and the other part becomes a loss, including optical loss and heat loss. To simplify the analysis, the following assumptions are made.

(1) Axial and transverse heat transfer of PV panel and absorber plate are independent of each other.

(2) The material properties of each module are independent of temperature, and the upper and lower surfaces are the same.

(3) The thickness of each module is small, so the temperature gradient along the thickness direction can be ignored.

(4) The effect of wavelength on solar absorptance is ignored.

The simplified thermal network diagram of $\mathrm{PV} / \mathrm{T}$ is shown in Figure 10. Its heat transfer process is shown as follows [19] :(1) Heat transfer between glass cover plate and external environment. The thermal resistance in this heat transfer process includes radiation thermal resistance $1 / h_{r, c-a}$ and convective thermal resistance $1 / h_{w}$. (2) Heat transfer between glass cover and PV panel. The heat transfer resistance between the $P V$ panel and the absorber plate is related to the manufacturing process. (3) Heat transfer between the absorber plate and the fluid in the flow channel. (4) Heat transfer between the backplate and the external environment. The thermal resistance in this heat 
transfer process also includes radiation thermal resistance $1 / h_{r, b-a}$ and convective thermal resistance $1 / h_{w}$.

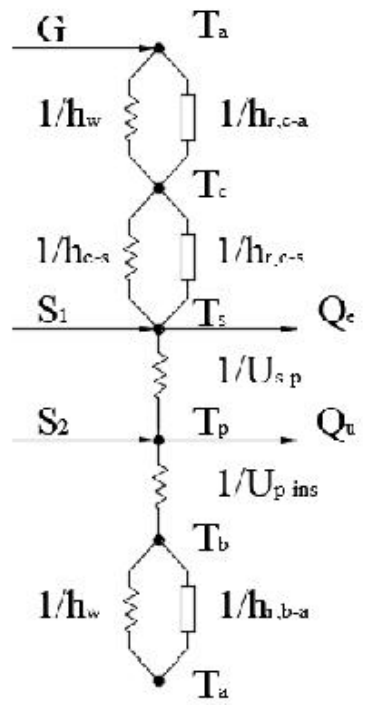

Figure 10: Thermal network diagram of $\mathrm{PV} / \mathrm{T}$.

\subsection{Establishment of Theoretical Mathematical Model}

\subsubsection{Thermal Performance Analysis of PV/T Collector}

The tube-sheet PV/T collector is divided into four modules, which are glass cover, PV panel, absorber plate and the fluid inflow channel. These four modules are represented by the symbols " $c$ ", "s", " $p$ " and " $f$ " respectively, and the external environment is represented by the symbol " $a$ ". According to the hypothesis, the following thermal performance analysis model was established.

\section{(1) Glass cover}

The energy balance equation of the glass cover is established as Eq.4 [17-18].

$$
U_{c-a} \cdot\left(T_{c}-T_{a}\right)=G \cdot \alpha_{c}+U_{s-c} \cdot\left(T_{s}-T_{c}\right)
$$

Where $G$ is the solar irradiance received by $\mathrm{PV} / \mathrm{T}$, $\mathrm{W} / \mathrm{m}^{2} ; U_{c-a}$ is heat transfer coefficient between the glass cover and the external environment, $\mathrm{W} /\left(\mathrm{m}^{2} \cdot \mathrm{K}\right) ; U_{s-c}$ is the heat transfer coefficient between the glass cover and the PV panel, $\mathrm{W} /\left(\mathrm{m}^{2} \cdot \mathrm{K}\right) ; \alpha_{c}$ is the absorptance of glass cover; $T_{c}$ is the temperature of the glass cover, ${ }^{\circ} \mathrm{C} ; T_{a}$ is the ambient temperature, ${ }^{\circ} \mathrm{C} ; T_{s}$ is the average temperature of the $\mathrm{PV}$ panel, ${ }^{\circ} \mathrm{C}$.
(2) PV panel

The energy balance equation of $\mathrm{PV}$ panel is established as Eq.5.

$$
S_{1} \cdot \alpha_{s}-E=U_{s-c} \cdot\left(T_{s}-T_{c}\right)+U_{s-p}\left(T_{s}-T_{p}\right)
$$

Where $S_{1}$ is the solar irradiance received by the PV panel, $\mathrm{W} / \mathrm{m}^{2} ; \alpha_{s}$ is the absorptance of PV panel; $E$ is the electricity generation of PV cells per unit area, $\mathrm{W} / \mathrm{m}^{2}$; $U_{s-p}$ is the heat transfer coefficient between PV cells and absorber plate, $\mathrm{W} /\left(\mathrm{m}^{2} \cdot \mathrm{K}\right) ; T_{p}$ is the temperature of the absorber plate, ${ }^{\circ} \mathrm{C}$.

(3) The heat transfer process of the absorber plate module is divided into two aspects: axial (i.e., flow direction) heat transfer and transverse heat transfer. The local structure of tube-sheet $\mathrm{PV} / \mathrm{T}$ is shown in Figure 11. The temperature gradient in the flow direction is not taken into account, and the absorber plate is a thin metal plate, so the temperature gradient in the thickness direction of the absorber plate can be ignored. From the analysis of the temperature distribution of the transverse tube-sheet structure, the temperature is the highest at the point between the two tubes. Regarding the center point of the two tubes as the coordinate of $x=0$, the temperature at this point can be expressed as $\left.\frac{d}{d x}\right|_{x=0}=0$. Therefore, the heat transfer process of the absorber plate module is treated as a typical two-dimensional fin problem with the tube-sheet joint as the rib base and the tube-sheet joint to the midpoint of the tube distance as the fin.

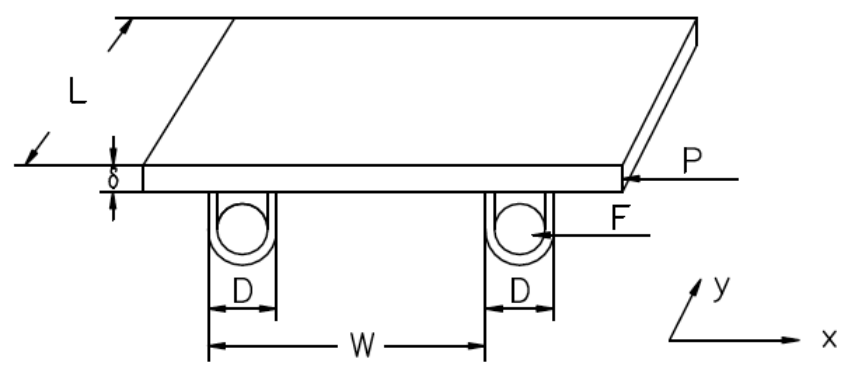

Figure 11: Tube-sheet structure diagram.

The energy balance equation of the absorber plate is established as Eq.6.

$$
\begin{aligned}
& S_{2} \cdot \alpha_{p}+U_{s-p} \cdot\left(T_{s}-T_{p}\right)+q_{f} \cdot D^{-1}= \\
& U_{p-a} \cdot\left(T_{p}-T_{a}\right)+U_{p-f} \cdot\left(T_{p}-T\right)
\end{aligned}
$$

Where $S_{2}$ is the solar irradiance received by the absorber plate, $\mathrm{W} / \mathrm{m}^{2} ; q_{f}$ is the heat transferred from the fin to the tube per unit length in the flow direction, $\mathrm{W} / \mathrm{m}$; 
$U_{p-a}$ is theedge and bottom heat loss coefficient of $\mathrm{PV} / \mathrm{T}, \quad \mathrm{W} /\left(\mathrm{m}^{2} \cdot \mathrm{K}\right) ; \quad U_{p-f}$ is heat transfer coefficient between the absorber plate and the fluid, $\mathrm{W} /\left(\mathrm{m}^{2} \cdot \mathrm{K}\right)$.

When calculating $q_{f}$, take a tube and the length of the fins on both sides, that is, $(W-D)$ is regarded as a unit. The heat transferred to the flow tube through the fins in the unit is first analyzed. The micro-element body with the width $\Delta x$ and the unit length in the flow direction is analyzed. The energy balance equation is Eq.7.

$U_{\mathrm{s}-p} \cdot\left(T_{s}-T_{p}\right) \cdot \Delta x+U_{p-a} \cdot\left(T_{a}-T_{p}\right) \cdot \Delta x+S_{2} \cdot \Delta x-\left.k_{p} \delta_{p} \frac{d}{d}\right|_{x}+$

$\left.k_{p} \delta_{p} \frac{d}{d}\right|_{x+d}=0$

Where $T_{p f}$ is the temperature of the transverse $\mathrm{x}$-axis of the fin, ${ }^{\circ} \mathrm{C} ; k_{p}$ is the thermal conductivity of the absorber plate, $\mathrm{W} /(\mathrm{m} \cdot \mathrm{K}) ; \delta_{p}$ is the thickness of the absorber plate, $\mathrm{m}$.

Eq.7 can be solved as follows:

$$
T_{p}(x)=T_{a}+\frac{Q}{U_{p-a}^{\prime}}-\left(T_{a}+\frac{Q}{U_{p-a}^{\prime}}-T_{p}\right) \cdot \frac{c h(\omega)}{c \cdot h\left(\omega \cdot \frac{W-D}{2}\right)}
$$

Where $\omega^{2}=\frac{u_{p-a}^{\prime}}{k_{p} \cdot \delta_{p}}$ and the boundary conditions are $\frac{d T}{d x} \mathrm{I}_{x=0}=0, T \mathrm{I}_{x=(W-D) / 2}=T p$.

Thus, the useful heat gains of the fin part per unit length is calculated as follows:

$q_{f}=(W-D) \cdot\left[Q-U_{p-a}^{\prime}\left(T_{p}-T_{a}\right)\right] \cdot F_{f}$

Where $F_{f}$ is the fin efficiency.

$$
F_{f}=\frac{t_{1} h \frac{\omega(W-D)}{2}}{\frac{\omega(W-D)}{2}}
$$

(4) Fluid in the flow tube

The heat balance equation of the fluid in the flow tube is established as Eq.11.

$q \cdot D^{-1}=U_{p-f} \cdot\left(T_{p}-T\right)$

Where $q$ is the heat flux of per unit length of the fluid on the $y$ axis (flow direction).

The effective use of energy is equal to the heat transferred to the fluid in the flow tube, and the efficiency factor $F^{\prime}$ of $\mathrm{PV} / \mathrm{T}$ is introduced.

$$
q=W \cdot F^{\prime} \cdot\left[Q-U_{L}\left(T-T_{a}\right)\right]
$$

Where,

$$
\begin{aligned}
& F^{\prime}=\frac{\frac{D}{W}\left(1+\frac{W-D}{D} F_{f}\right)}{1+U_{L}\left(1+\frac{W-D}{D} F_{f}\right) \cdot\left(\frac{1}{c_{b}}+\frac{1}{\pi D_{i} h_{f, i}}\right)} \\
& =\frac{\frac{1}{U_{L}}}{w\left\{\frac{1}{U_{L}\left[D+(W-D) F_{f}\right]}+\frac{1}{c_{b}}+\frac{1}{\pi D_{i} h_{f, i}}\right\}}
\end{aligned}
$$

\subsubsection{Solving the Thermal Model of PV/T Collector}

In order to analyze the temperature change of the fluid in the y-direction of the flow, the Taylor expansion of the heat in the direction of the fluid flow is carried out.

$$
q(T) \approx \not(T)=q\left(T_{a}\right)+q^{\prime}\left(T_{a}\right)\left(T-T_{a}\right)
$$

Where $q(T)$ represents the approximate value, and $q^{\prime}\left(T_{a}\right)=\left.\frac{d}{d}\right|_{T-T_{a}}$.

Then, in the y-direction, a micro-element body of length $d y$ is taken, and the balanced equation of this body is expressed as Eq.15.

$\dot{m} C_{p}[T(y+d)-T(y)]=\tilde{q}(T(y)) d$

Where $\dot{m}$ is the mass flow rate of fluid; $C_{p}$ is the specific heatcapacity of the fluid.

The above differential equation can be solved as follows:

$$
T(y)=T_{a}-\frac{q\left(T_{a}\right)}{q^{\prime}\left(T_{a}\right)}-\left(T_{a}-T_{i}-\frac{q\left(T_{a}\right)}{q^{\prime}\left(T_{a}\right)}\right) e . \quad\left(\frac{q^{\prime}\left(T_{a}\right) y}{m c_{p}}\right)
$$

Where $T_{i}$ is the temperature of inlet fluid.

According to Eq.5, the temperature of the PV panel can be written:

$$
\begin{aligned}
& T_{s}(x, y)=\left(U_{s-p}+U_{s-a}-c_{1}\right)^{-1}\left[\left(\left\{\tau_{c} \alpha_{s}\right\}-\left(\eta_{0}+c T_{a}\right)\right) G+\right. \\
& \left.U_{s-a} T_{a}+U_{s-p} T_{p}(x, y)\right]
\end{aligned}
$$

Since $T_{p}$ varies with the variable $\mathrm{y}, T_{p}(x, y)$, in the equation also varies with the variable $y$. It is known that: 


$$
T_{p}(y)=T(y)+\frac{q(T(y))}{D U_{p-f}}
$$

\subsection{Theoretical Analysis and Calculation of Thermal Performance of the PV/T Collector}

According to the performance analysis of the theoretical model, take the inlet water temperature as $30^{\circ} \mathrm{C}$, the irradiance under the reference experimental conditions to be $850 \mathrm{~W} / \mathrm{m}^{2}$, the ambient temperature to be $10^{\circ} \mathrm{C}$, the mass flow to be $0.03 \mathrm{~kg} / \mathrm{s}$, and the electrical efficiency to be assumed to be $10 \%$ as an example. The theoretical analysis and calculation are carried out. The specific values of various parameters required in the calculation are shown in Table 1, and the following contents:

The absorptance of PV panel $a_{s}=0.725$; the emissivity of PV panel $\varepsilon_{s}=0.8$; the reflectance of PV panel $\rho_{s}=0.075$; the transmittance of PV panel $\tau_{s}=$
0.2 ; the convective heat transfer coefficient between the tube wall and the fluid $h_{f, I}=300 \mathrm{~W} /\left(\mathrm{m}^{2} \cdot \mathrm{K}\right)$; the average thickness of the junction $\lambda=1 \mathrm{~mm}$; the thermal conductivity of the welding material $k_{b}=385$ $\mathrm{W} /(\mathrm{m} \cdot \mathrm{K})$; the average width of the weld $b \approx D=8 \mathrm{~mm}$.

In the experimental test, it was found that the average temperature of the PV panel and the temperature of the inlet water were large. Therefore, the theoretical calculation focuses on the analysis of the temperature of the PV panel. Based on the heat transfer resistance between the PV panel and fluid water tested in the experiment, the theoretical calculation of the surface temperature distribution of the PV panel in one unit of the tube-sheet structure is shown in Figure 12. It can be seen from Figure 12 that there is a temperature gradient in the transverse direction of the PV panel. The temperature at the midpoint of the tube distance is the highest, and the temperature at the junction of the tube sheet is the

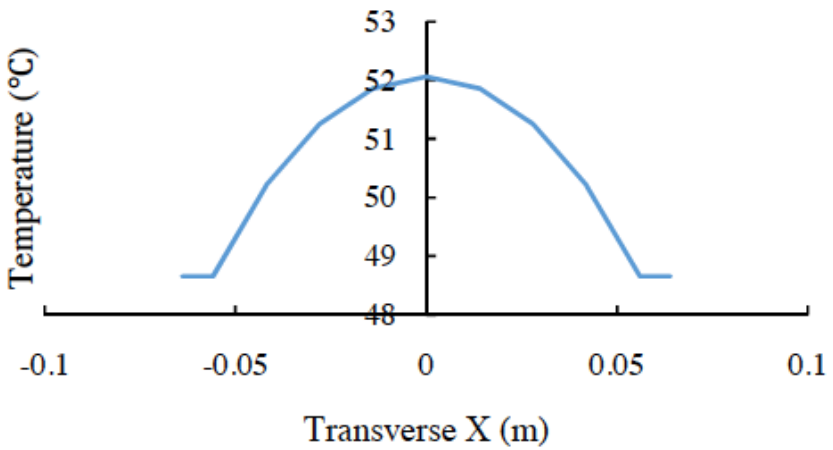

(a) Temperature distribution of the cross section of the unit PV panel in the middle of the flow direction.

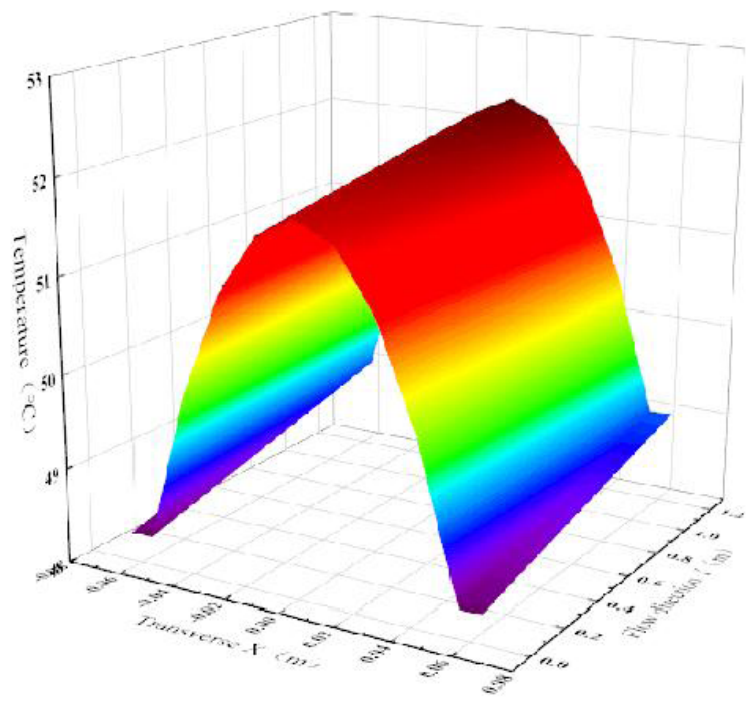

(b) Temperature distribution on the surface of the unit PV panel.

Figure 12: Theoretical calculation of the temperature distribution on the surface of the PV panel. 
lowest. The average temperature difference between the midpoint of the tube distance and the junction of the tube-sheet is about $3.4^{\circ} \mathrm{C}$. In the flow direction, the water temperature rise at the $1.2 \mathrm{~m}$ outlet is about $1.19^{\circ} \mathrm{C}$, and the water temperature rise gradient gradually decreases, so that the temperature rise gradient of the PV panel in the flow direction also gradually decreases.

The temperature difference between the average temperature of the $\mathrm{PV}$ panel and the inlet water temperature is about $20.8^{\circ} \mathrm{C}$, which is close to the daily average temperature difference of $22.5^{\circ} \mathrm{C}$ under the experimental test condition. It is determined that the main reason for the large temperature difference between the PV panel and the water temperature is between the PV panel and the absorber plate, that is, the intermediate combined thermal resistance between the PV panel and the absorber plate is large. The theoretical calculation of the thermal efficiency under this condition is about $30.5 \%$, heat loss is about $41.2 \%$. The thermal efficiency is higher than that of the experimental result. Because the experimental results are the synthesis of effective data within a day, there are certain differences between the theoretical analysis and the experimental results, but the difference is within the range of $10 \%$, and the performance regular is in accordance with the experiment. The results of theoretical calculation and experimental test of heat collection performance are shown in Table $\mathbf{5}$. With the increase of the average temperature of the PV panel, the electrical efficiency decreases. As the thermal performance of the PVT collector is more valuable than the electrical efficiency, using cover glass in front of $P V$ panels is good for thermal performance.

\section{(1) Effects of combined thermal resistance}

According to Eq. 13, in order to further improve the thermal collection performance of $P V / T$, the thermal resistance between the $\mathrm{PV}$ panel and the absorber plate should be firstly reduced, that is, the thermal resistance between the PV panel and the fluid should be reduced.
The ambient temperature and the inlet water temperature remain unchanged. When the thermal resistance between the PV panel and the fluid decreases, the thermal resistance of the fluid to the external environment decreases, that is, the heat transfer coefficient of the fluid to the external environment increases. Other conditions remain unchanged, and theoretical calculations are carried out. The results show that the temperature difference between the PV panel and the inlet water temperature is about $15.9^{\circ} \mathrm{C}$, and the temperature difference decreases. According to the theoretical calculation, the thermal efficiency is about $34.7 \%$, the heat loss is about $37.1 \%$, and the thermal efficiency can be significantly improved. Therefore, reduction of the thermal resistance between the PV panel and the fluid can improve the heat transfer performance, optimize the thermal collection performance of PV/T. The method of reducing the thermal resistance between the PV panel and the fluid can start by reducing the combined thermal resistance of the PV panel and the absorber plate. For example, the PV panel and the absorber plate are bonded more closely by laminating.

\section{(2) Effects of solar irradiance}

The intensity of solar irradiance is one of the factors affecting the thermal performance of PV/T. Only the intensity of solar irradiance is changed to $950 \mathrm{~W} / \mathrm{m}^{2}$, other conditions remain unchanged. The results of the theoretical calculation show that the temperature difference between the average temperature of the PV panel and the inlet water temperature is about $24.4^{\circ} \mathrm{C}$, and the temperature difference increases. According to the theoretical calculation, the thermal efficiency is about $32.1 \%$, the heat loss is about $39.9 \%$, and the thermal efficiency is improved. Therefore, increasing the intensity of solar irradiation can improve the thermal collection performance of $\mathrm{PV} / \mathrm{T}$.

\section{(3) Effects of the ambient temperature}

The outdoor ambient temperature mainly affects the heat loss of $\mathrm{PV} / \mathrm{T}$. The higher the ambient temperature, the smaller the heat loss, thus improving the thermal

Table 5: Thermal Performance of Experimental and Theoretical Analysis Under Inlet Water Temperature of $30^{\circ} \mathrm{C}$

\begin{tabular}{|c|c|c|c|}
\hline Projects & Outlet Water Temperature $\left({ }^{\circ} \mathrm{C}\right)$ & Average Temperature of PV Panel $\left({ }^{\circ} \mathrm{C}\right)$ & Thermal Efficiency $(\%)$ \\
\hline \hline Experimental test & 31.21 & 52.57 & 28.7 \\
\hline Theoretical calculation & 31.19 & 50.80 & 30.5 \\
\hline
\end{tabular}




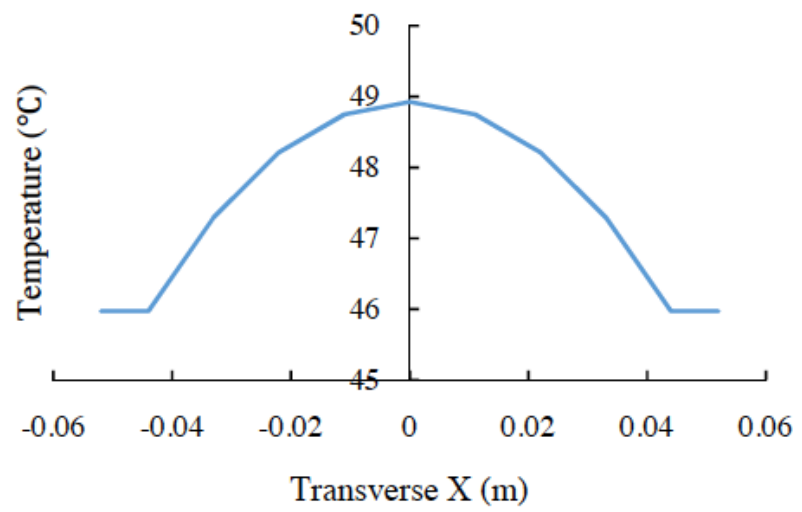

(a) Temperature distribution of the cross-section of the unit PV panel in the middle of the flow direction.

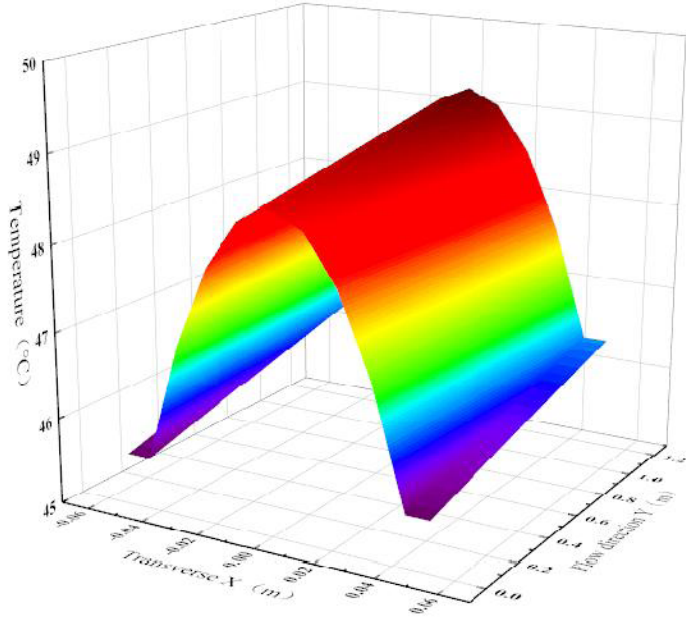

(b) Temperature distribution on the surface of the unit PV panel.

Figure 13: Temperature distribution on the surface of the PV panel when the tube spacing is $96 \mathrm{~mm}$.

collection performance of $\mathrm{PV} / \mathrm{T}$. Only the ambient temperature is increased to $15^{\circ} \mathrm{C}$ and other conditions remain unchanged. The temperature difference between the average temperature of the PV panel and the inlet water temperature is about $23.2^{\circ} \mathrm{C}$, and the temperature difference increases. According to theoretical calculation, the thermal efficiency is about $33.9 \%$, the heat loss is about $37.9 \%$, and the thermal efficiency is significantly improved. Therefore, by increasing the outdoor ambient temperature, the heat loss of $\mathrm{PV} / \mathrm{T}$ can be reduced and the thermal collection performance of $\mathrm{PV} / \mathrm{T}$ can be improved. However, as the temperature of $\mathrm{PV}$ panel rises, their electrical efficiency will decrease.

\section{(4) Effects of the spacing of the row tubes}

In addition, the temperature distribution of $\mathrm{PV}$ panel and absorber plate is affected by the spacing of the row tubes. A reasonable spacing of the row tubes can reduce the transverse temperature difference, thereby making the temperature distribution of the absorber plate and PV panel much uniform.

When the tube spacing is $96 \mathrm{~mm}$, the PV panel area remains unchanged. The calculated theoretical temperature distribution of the PV panel surface in one unit of the tube-sheet structure is shown in Figure 13. It can be seen from Figure 13 that the average temperature difference between the midpoint of the transverse tube spacing of the PV panel and the junction of the tube-sheet is about $2.9^{\circ} \mathrm{C}$.

The temperature difference between the average temperature of the PV panel and the inlet water temperature is about $17.8^{\circ} \mathrm{C}$, and the temperature difference decreases. Theoretical calculation of the thermal efficiency under this condition is about $32.4 \%$, heat loss is about $39.4 \%$. The thermal efficiency is improved, which indicates that optimization of spacing of the row tubes can improve temperature distribution and thermal collection performance. The theoretical 
Table 6: The Theoretical Calculation Results of the Four Conditions

\begin{tabular}{|c|c|c|c|c|}
\hline Conditions & Outlet Temperature $\left({ }^{\circ} \mathbf{C}\right)$ & $\begin{array}{c}\text { Average Temperature } \\
\text { of PV Panel }\left({ }^{\circ} \mathbf{C}\right)\end{array}$ & Thermal Efficiency (\%) & Heat Loss (\%) \\
\hline $\begin{array}{c}\text { Reduce combined thermal } \\
\text { resistance }\end{array}$ & 1.35 & 45.9 & 34.7 & 37.1 \\
\hline Change solar irradiance & 1.39 & 54.4 & 32.1 & 39.9 \\
\hline $\begin{array}{c}\text { Change the ambient } \\
\text { temperature }\end{array}$ & 1.32 & 53.2 & 37.9 & 37.9 \\
\hline Reduce the tube spacing & 1.26 & 47.8 & 39.4 \\
\hline
\end{tabular}

calculation results of the four conditions are shown in Table 6.

From the above four conditions, we can find that reduce combined thermal resistance has the greatest impact on the thermal efficiency, followed by changing the ambient temperature, reduce the tube spacing and change solar irradiance. To increase the efficiency to higher values, reducing combined thermal resistance is a preferred method.

\section{CONCLUSIONS}

This paper studied and analyzed the electricity generation and thermal collection performances of tube-sheet PV/T collector from two aspects of experimental test and theoretical analysis. The main conclusions are summarized as follows.

(1) According to the principle of PV/T test system, an experimental platform was built to test the electrical and thermal performances of tube-plate PV/T. According to the experimental results, under the experimental conditions of the inlet water temperature of $30^{\circ} \mathrm{C}$, the daily average temperature difference between the average temperature of $\mathrm{PV}$ panel and the inlet water temperature was about $22.5^{\circ} \mathrm{C}$, which was considered to be a large temperature difference. The daily average electrical efficiency was about $9.25 \%$, and the daily average thermal efficiency was about $28.67 \%$. As solar irradiance increases, both the electrical and thermal efficiencies of PV/T increase. In the flow resistance test, the pressure loss of tube-sheet $\mathrm{PV} / \mathrm{T}$ is not large, and the pressure loss is mainly along with the frictional, split and confluence loss.

(2) According to the structure of the tube-sheet $\mathrm{PV} / \mathrm{T}$, the heat transfer mathematical model of the device was established. The thermal performance of $\mathrm{PV} / \mathrm{T}$ under inlet water temperature of $30^{\circ} \mathrm{C}$ was theoretically analyzed and calculated, and the calculated results were close to the experimental results. Therefore, it is determined that the reason for the high temperature of $\mathrm{PV}$ panel lies in the larger combined thermal resistance between the PV panel and the absorber plate. Heat transfer performance can be improved by reducing the combined thermal resistance between the PV panel and the absorber plate, that is, the thermal resistance between the PV panel and the fluid.

(3) In addition, solar irradiance, outdoor ambient temperature and spacing of the row tubes are all influencing factors of the thermal collection performance of $\mathrm{PV} / \mathrm{T}$. Reducing the spacing of the row tubes can reduce the transverse temperature difference of PV panel and optimize the temperature distribution of $\mathrm{PV}$ panel and absorber plate.

\section{REFERENCE}

[1] Kern EC, Russell MC. Combined photovoltaic and thermal hybrid collector systems. //IEEE Photovoltaic Specialists Conference. Washington, 1978: 1153-1157.

[2] Florschuetz LW. Extension of the Hottel-Whillier model to the analysis of combined photovoltaic/thermal flat plate collectors. Solar Energy, 1979; 22(4): 361-366. https://doi.org/10.1016/0038-092X(79)90190-7

[3] Bergene T, Lovvik OM. Model calculations on a flat-plate solar heat collector with integrated solar cells. Solar Energy, 1995; 55(6): 453-462.

https://doi.org/10.1016/0038-092X(95)00072-Y

[4] Chow TT, Pei G, Fong KF, et al. Energy and exergy analysis of photovoltaic-thermal collector with and without glass cover Applied Energy, 2009; 86(3): 310-316. https://doi.org/10.1016/j.apenergy.2008.04.016

[5] Ibrahim A, Othman M Y, Ruslan MH, et al. Recent advances in flat plate photovoltaic/thermal (PV/T) solar collectors. Renewable and Sustainable Energy Reviews, 2011; 15(1): 352-365.

https://doi.org/10.1016/j.rser.2010.09.024

[6] Dupeyrat $\mathrm{P}$, Rommel M, Henning H M. Efficient single glazed flat plate photovoltaic-thermal hybrid collector for domestic hot water system. Solar Energy, 2011; 85(7): 1457-1468. https://doi.org/10.1016/j.solener.2011.04.002

[7] Fudholi A, Sopian K, Yazdi MH, et al. Performance analysis of photovoltaic thermal (PVT) water collectors. Energy Conversion and Management, 2014; 78: 641-651. https://doi.org/10.1016/j.enconman.2013.11.017 
[8] Aste N, Leonforte F, Pero CD. Design, modeling and performance monitoring of a photovoltaic-thermal (PVT) water collector. Solar Energy, 2015; 112: 85-99. https://doi.org/10.1016/i.solener.2014.11.025

[9] Ramdani $\mathrm{H}$, Ould-Lahoucine $\mathrm{C}$. Study on the overall energy and exergy performances of a novel water-based hybrid photovoltaic-thermal solar collector. Energy Conversion and Management, 2020, 222. https://doi.org/10.1016/j.enconman.2020.113238

[10] Bilbao JI, Sproul AB. Detailed PVT-water model for transient analysis using RC networks. Solar Energy, 2015; 115: 680693.

https://doi.org/10.1016/j.solener.2015.03.003

[11] Sakellariou E, Axaopoulos P. An experimentally validated, transient model for sheet and tube PVT collector. Solar Energy, 2018; 174: 709-718. https://doi.org/10.1016/j.solener.2018.09.058

[12] Turkyilmazoglu M. Efficiency of heat and mass transfer in fully wet porous fins: Exponential fins versus straight fins. Int J Refrig 2014; 46: 158-64 https://doi.org/10.1016/j.jirefrig.2014.04.011

[13] Turkyilmazoglu M. Stretching/shrinking longitudinal fins of rectangular profile and heat transfer. Energy Convers Manag 2015; 91: 199-203. https://doi.org/10.1016/j.enconman.2014.12.007

[14] Turkyilmazoglu M. Heat transfer from moving exponential fins exposed to heat generation. Int J Heat Mass Transf 2018;
116: 346-51.

https://doi.org/10.1016/j.ijheatmasstransfer.2017.08.091

[15] Zhou J, Ke H, Deng X. Experimental and CFD investigation on temperature distribution of a serpentine tube type photovoltaic/thermal collector. Solar Energy, 2018; 174: 735742.

https://doi.org/10.1016/j.solener.2018.09.063

[16] Yu Y, Long E, Chen $\mathrm{X}$, Yang $\mathrm{H}$. Testing and modelling an unglazed photovoltaic thermal collector for application in Sichuan Basin. Applied Energy, 2019; 242: 931-941. https://doi.org/10.1016/j.apenergy.2019.03.114

[17] Yu G, Wu J, Zhou J, et al. Test method for flow pressure loss in liquid piping equipment: China, 201310012570.8. 2015-0722.

[18] Ji J, Pei G, He W, et al. Research progress on solar photovoltaic/ thermal systems utilization. Beijing, China: Science Press, 2017.

[19] Duffie JA, Beckman WA. Solar Engineering of Thermal Processes. 4th ed. New York, USA: Wiley, 2013. https://doi.org/10.1002/9781118671603

[20] Bergene T, Lovvik OM. Model calculations on a flat-plate solar heat collector with integrated solar cells. Solar Energy, 1995; 55(6): 453-462. https://doi.org/10.1016/0038-092X(95)00072-Y

[21] Zhang X, Ren Z, Mei F. Heat transfer. 5th ed. Beijing, China: China Building Industry Press, 2007.

Received on 19-05-2021

Accepted on 25-06-2021

Published on 06-07-2021

DOI: https://doi.org/10.31875/2410-2199.2021.08.5

(C) 2021 Yang et al.; Zeal Press.

This is an open access article licensed under the terms of the Creative Commons Attribution Non-Commercial License (http://creativecommons.org/licenses/by-nc/3.0/), which permits unrestricted, non-commercial use, distribution and reproduction in any medium, provided the work is properly cited. 